\title{
Teaching Bank Runs with Classroom Experiments by
}

\author{
Dieter Balkenborg, Todd Kaplan and Timothy Miller
}

University of Exeter

\begin{abstract}
Once relegated to cinema or history lectures, bank runs have become a modern phenomenon that captures the interest of students. We use a simple classroom experiment based upon the Diamond-Dybvig Model (1983) to demonstrate how a bank run, a seemingly irrational event, can occur rationally. We then present possible topics for discussion including various ways to prevent bank runs and moral hazard.
\end{abstract}

Keywords: Bank Runs, Classroom Experiments, Multiple Equilibria.

JEL codes: C9, G2.

\section{Introduction}

The subprime crisis has led to spectacular events in the world of finance. Bank runs, once relegated to cinema or history lectures, have become a modern phenomenon. For the UK, the queues formed during the Northern Rock bank run have been imprinted on our memory. The run and subsequent suspension of payments of Icelandic banks has led to widespread losses. These dramatic events have generated interest among students wishing for understanding. In this paper, we offer a teaching experiment based upon the Diamond-Dybvig (1983) model that will help the students better understand bank runs and hence the current crisis.

In this paper, we will describe both a computerized Internet version and a noncomputerized version of the experiment. Both can be run conveniently in less than an hour with some time left for discussion. The computerized version can be run over the Internet using our Finance and Economics Experimental Laboratory at Exeter (FEELE) website. In the next section we describe the game illustrating the DiamondDybvig model and its analysis in more detail. In Section 3 we describe the computerized version and the hand-run version of the experiment. Section 4 discusses some results obtained from running the experiments. The Appendix provides instructions needed for the hand-run version

\section{Description and Analysis of the Diamond-Dybvig Model}

Our experiment is based upon the Diamond-Dybvig model (1983), which captures several elements of what a bank does. Our experiment focuses on the conversion of 
long-term loans (mortgages) into short-term deposits. ${ }^{1}$ It is this conversion that leads to the inherent problem of bank runs.

In the model, there are depositors and a bank. There are three time periods: yesterday, today and tomorrow. Depositors placed money (say £1000) in a bank (yesterday) before learning when they need the money (their preferences). Depositors either need their money today (are impatient) or tomorrow (are patient). There is a $50 \%$ chance of needing the money at either time. The depositors that need money today get relatively very little utility for the money tomorrow. The depositors that need their money tomorrow can always take the money today and hold onto it.

The bank has both a short term and a long term investment opportunity for the money. The short term investment (reserves) is equivalent to locking the money in the vault. This investment returns the exact amount invested. The long term investment returns an amount $\mathrm{R}$ tomorrow. It is illiquid and returns only $\mathrm{L}<1$ today.

The depositors that invested $£ 1000$ yesterday have a contract with the bank. They can withdraw their money today and receive $£ 1000$ or wait until tomorrow and receive $R^{*} £ 1000$. Note, the bank needs to offer a contract contingent upon withdrawal time, since it does not know which depositors are patient and which are impatient, just the overall fraction.

The bank that received deposits yesterday had to decide how to meet the potential demands of today and tomorrow. How does the bank meet this contract? The bank can divide the money into two parts. Take half and keep it as reserves. Take the other half and put it in the long term investment. Say there are 10 depositors: 5 impatient and 5 patient. If the 5 impatient depositors withdraw today and the 5 patient depositors withdraw tomorrow, the demands are $5 * 1000$ today and $5 * \mathrm{R} * 1000$ tomorrow. If the bank puts $£ 5000$ in the vault and invests $£ 5000$, then the bank has 5000 today and $\mathrm{R} * 5000$ tomorrow and can fulfil the demands. ${ }^{2}$

What the above shows us is that if all the depositors withdraw the money according to their types, then the bank will meet all the demands. In this case, each depositor has incentive to indeed withdraw according to his true type. An impatient depositor prefers 5000 today to $\mathrm{R} * 5000$ tomorrow. A patient depositor prefers $\mathrm{R} * 5000$ tomorrow to 5000 today. Hence, all impatient depositors withdrawing today and all patient depositors withdrawing tomorrow is a Nash equilibrium. ${ }^{3}$

While the contract is fulfilled in this Nash equilibrium, in other cases the bank cannot always remain solvent. If too many depositors try to withdraw today, it won't be able to meet the contract tomorrow. For instance, if 7 out of 10 depositors withdraw

\footnotetext{
${ }^{1}$ The Diamond Dybvig model also captures a risk-sharing aspect of banking, namely, insuring depositors against needing money earlier rather than later. The contract used in our experiment is not the optimal risk-sharing contract, but one chosen to best illustrate the potential of bank runs.

${ }^{2}$ We should also note that we are assuming that the bank makes zero profit (the industry is competitive).

${ }^{3}$ An astute reader will note that a bank may not be able to pay the R*5000 tomorrow if 6 depositors withdraw tomorrow since it will only have 1000 from its reserves and $\mathrm{R} * 5000$ from the long-term asset; however, if the impatient depositor prefers 5000 today to $\mathrm{R} * 5000$ tomorrow, then he would also prefer 5000 today to whatever amount the bank can pay tomorrow, since that amount is less than $\mathrm{R} * 5000$.
} 
today, then the bank can pay 5000 out of reserves. It then must sell its illiquid longterm asset to meet the rest of the needs. The amount that must be liquidated is $\mathrm{X}$ such that $\mathrm{X}^{*} \mathrm{~L}=2000$. The remaining amount to pay the 3 depositors tomorrow is (5000$(2000 / \mathrm{L}))^{*} \mathrm{R}$. If, for instance, $\mathrm{R}=2$ and $\mathrm{L}=.5$, then this amount is 2000. Per depositor, this is less than the expected amount paid for withdrawing early. If a patient depositor thought 7 of the other depositors would withdraw early, then he would do better withdrawing early and receiving on average $(5000+5000 * \mathrm{~L}) / 8=937.5$ rather than waiting until tomorrow and receiving on average $2000 / 3=667$.

We can see that this leads to multiple (Nash) equilibria which are inherent in banking. One of the equilibria is the bank-run equilibrium. It is fairly easy to see this by looking at the equilibria with 2 impatient depositors and 2 patient depositors. Yesterday, each of the 4 depositors invested $£ 1000$. The bank then invests $£ 2000$ in the short-term investment and $£ 2000$ in the long-term investment. Today, two of the depositors learn they are impatient and withdraw the money today (it is their dominant strategy). The remaining two patient depositors have to decide whether to withdraw their money today or tomorrow. We can model their behaviour in a $2 \times 2$ normal form game.

Let us look at this game when $\mathrm{R}=1.5$ and $\mathrm{L}=.5$. If both patient depositors wait until tomorrow they would both receive $£ 1500$. If one withdraws today and the other tomorrow, the one withdrawing today receives $£ 1000$; however, the one withdrawing tomorrow will receive 0 because the bank needs to liquidate all its long-term investment to meet the extra demand of $£ 1000$ today ( $£ 2000 * \mathrm{~L}=£ 1000)$. If both try to withdraw today, then the bank still needs to liquidate all of its long-term assets. Now the bank doesn’t have enough to fulfil the extra $£ 2000$ demanded by its contract. How much can the bank pay out? It has $£ 2000$ in the short term investment and $£ 1000$ from liquidating its long-term. It has to divide this among the 4 depositors withdrawing today (two patient and two impatient). Thus, on average, each would receive $£ 750$. All these payoffs form the normal form game presented below: 


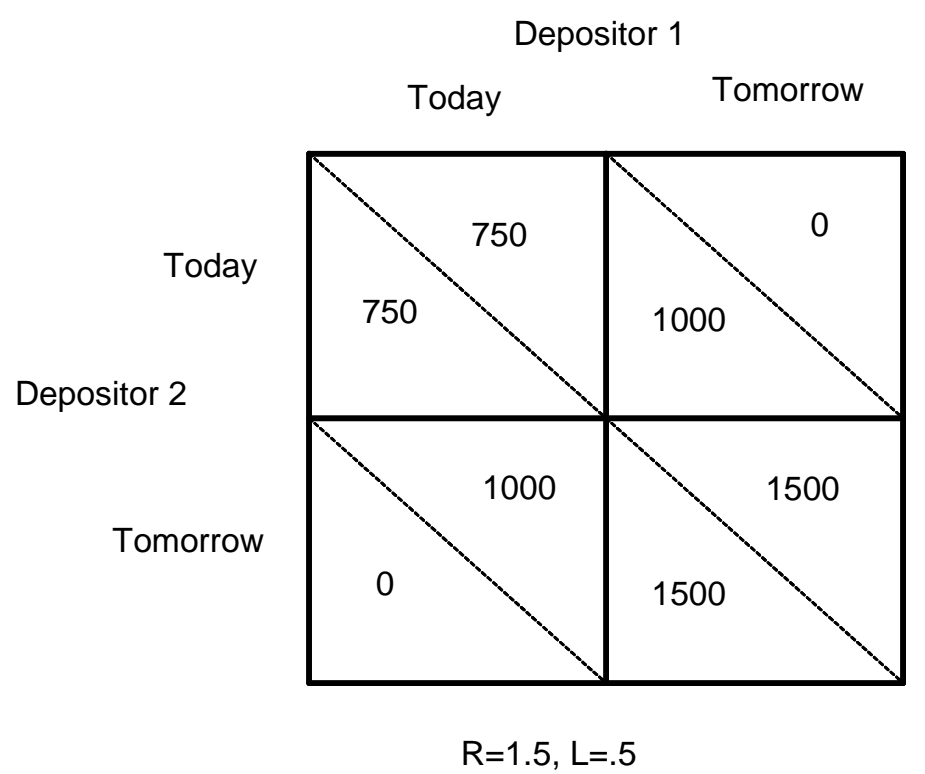

There are two pure-strategy Nash equilibria of this game: both patient depositors withdrawing today and both patient depositors withdrawing tomorrow. The bank run equilibrium is where both withdraw today. While this equilibrium is Pareto inferior, both have incentive to withdraw today since single-handedly deviating to withdrawing tomorrow will yield a payoff of zero. Hence, we theoretically demonstrate that while damaging, a bank run can be a rational, equilibrium phenomena. In the next section, we show how one can also demonstrate a bank run in the laboratory.

\section{Experimental procedure}

\section{Non-computerized}

Two versions of the Diamond Dybvig Model are run simultaneously in five rounds where students submit decisions for the patient depositors. Each student in a group of seven must decide simultaneously whether to withdraw money today or tomorrow. The game has two pure strategy Nash equilibria, everyone withdraws today or nobody withdraws today. Payoffs are higher when nobody withdraws today. The game has a "white" version and a "green" version. The "white" version requires less other depositors to withdraw today in order for it to be profitable to do so as well. Almost invariably, students coordinate on the withdraw today equilibrium in the "white" version and on the withdraw tomorrow equilibrium in the "green" version.

Timing: The experiment takes up to 30 minutes overall. Additional time may be allocated to more class discussion, possibly in a different lecture.

Preparation: It can save time if students are given instruction sheets at least a day before the actual experiment. This is particularly important if not all students are native English speakers. 
Preparation of Decision Sheets: The students should be divided into two roughly equal sized groups. Each group should get differently coloured decision sheets (we used white and green). The decision sheets can be cut into the five decision strips and stapled. One not very time consuming procedure is to take two types of coloured paper and just use a paper cutter to cut strips. Ask the students to take 5 strips at the beginning of class. Alternatively, one can simply print the sheets with the round numbers, 1-5, written on them, a blank for the name and the two choices to circle. Have the students tear off the decision strips during the experiments.

\section{To be planned in advance:}

- How are you going to split the students into two groups, e.g. male/female or left/right half of the room? Does the room design provide a natural way to do the split?

- Do you wish to use two students, one for each version (white/green) to collect the decision strips?

- Will you give the students the data to evaluate the experiment? How?

- If you want to give money / prizes decide how. (In one version, we had 20 candies and in another £20 available which we would use to pay one randomly selected student according to his gains in one randomly selected round.)

- The design below, where each student in, say, the white group plays against the decisions of six randomly selected members of the white group, is made for large classes. In smaller classes one may count how all students in the group decided and let each student play against that statistic. (Notice that some students play against themselves in our design, but this does not affect the Nash equilibria.) If you have fewer than 14 students in your class, further adjustments of the design are needed, which we leave to the instructor.

\section{Procedure:}

Choose two students as assistants to help you in running the experiment, one for each colour. Give them the differently coloured decision slips and the instructions and explain them how to distribute them. While the students distribute the sheets, draw the table for the results at the board. Summarize the main points from the instruction sheets.

Give the students three minutes (later 1 minute) to make their choices and turn in the decision strips. Advise the students to write down their own decisions for themselves on a separate piece of paper. You may require that the decision strips contain round, name and decision (1 or 2). Alternatively, you can just require the decision and collect the sheets using different plastic bags for each round.

Ask the two assistants to collect up the decision strips for each group separately. Suppose the decisions of the white group are collected first. Then select randomly six decision strips from the white group. Write on the board how many of the six students chose 1 and how many 2. Given these six choices, state the payoff of any student who chose 1 and that of any student who chose 2. Do the same for the green group. 
Repeat the above for rounds 2, 3, 4 and 5.

After the experiment, to save your time and to help the students learn, you may want to hand the data (slips) collected to small groups of students for writing summary evaluations.

The following table provides numbers that worked successfully in practice. These numbers were generated using $\mathrm{R}=1.2, \mathrm{~L}=0.2$ and a $£ 10$ deposit for the white group and $\mathrm{R}=2.0, \mathrm{~L}=0.8$ and $\mathrm{a} £ 10$ deposit for the green group.

\begin{tabular}{|l|l|l|l|l|l|l|l|}
\hline $\begin{array}{l}\text { Of the 6 others in } \\
\text { your group, the } \\
\text { number that choose 2 }\end{array}$ & 0 & 1 & 2 & 3 & 4 & 5 & 6 \\
\hline $\begin{array}{l}\text { Your amount if you } \\
\text { choose 2 and are in a } \\
\text { white group. }\end{array}$ & $£ 0$ & $£ 0$ & $£ 0$ & $£ 0$ & $£ 0$ & $£ 4$ & $£ 12$ \\
\hline $\begin{array}{l}\text { Your amount if you } \\
\text { choose } 1 \text { and are in a } \\
\text { white group }\end{array}$ & $£ 6$ & $£ 6$ & $£ 7$ & $£ 8$ & $£ 8$ & $£ 9$ & $£ 10$ \\
\hline $\begin{array}{l}\text { Your amount if you } \\
\text { choose 2 and are in a } \\
\text { green group. }\end{array}$ & $£ 0$ & $£ 8$ & $£ 13$ & $£ 16$ & $£ 18$ & $£ 19$ & $£ 20$ \\
\hline $\begin{array}{l}\text { Your amount if you } \\
\text { choose } 1 \text { and are in a } \\
\text { green group. }\end{array}$ & $£ 9$ & $£ 10$ & $£ 10$ & $£ 10$ & $£ 10$ & $£ 10$ & $£ 10$ \\
\hline
\end{tabular}

Notice that in both cases, there are two pure-strategy equilibria. If one believes that 6 others will withdraw at time 2 (tomorrow), it is worthwhile to withdraw at time 2. If one believes that no one else would withdraw at time 2, it does not make sense to withdraw at time 2 .

After one or two rounds, the two groups will diverge: members of the white group will choose time 1 , while members of the green group will choose time 2 . The white group in all likelihood will go to the bank run equilibrium.

\section{Computerized (Feele Lab website)}

\section{Detailed Procedure}

The computerized version of this experiment is available on the Feele Lab website. The procedure for setting up and running this experiment for the first time is as follows: (1) locate the Feele Lab homepage, (2) optionally, do a quick test log-in, to experience the experiment from the point of view of one of your students, (3) register your email address to obtain an experimenter's username and password, (4) log in as an experimenter, (5) create a new Diamond Dybvig experiment, (6) add a default session to this experiment, (7) change some of the default configuration values, e.g. number of subjects, (8) start the session running, (9) invite your students to log in to the session as 'subjects' while you watch the 'Monitor Log-Ins' screen, (10) start the 
experiment running, and (11) watch the 'View Results' screen to observe your students making decisions.

To locate the Feele Lab homepage, do a Google search for the word 'feele' and click on the first link, FEELE Laboratory. ${ }^{4}$

To do a quick test log-in, pretending to be a student, click on the large-font link, Lecturers: Run Experiments here, to display the Lecturers: Run Teaching Experiments page then, in the Quick Log-In section, click on the bullet-pointed

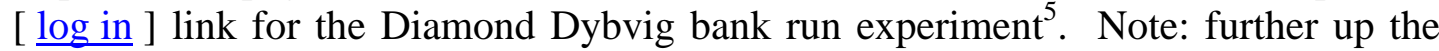
page, in the Getting Started section, is an Economics Network Presentation (MS PowerPoint) which you may find helpful; right at the end of it is a series of screenshots explaining how to register and $\log$ in as an experimenter and create your first experiment.

To register your email address, start from the Lecturers: Run Teaching Experiments page (see above) and click on Experimenter (lecturer) access (new window); ${ }^{6}$ the browser should open a new tab showing the Feele Lab Experimenter Access page. Click on the Register button [New Experimenter Registration] to bring up the Experimenter Registration page. Now enter your initials, your email address and your first and last names; your username will be emailed to you and consists of the initials you entered plus a numeric suffix. For the sake of an example, let us assume that your username is 'abc1'.

To log in as an experimenter for the first time, click on the Login Now button and enter your new username and password in the boxes provided on the Experimenter Login screen. (On subsequent occasions when you log in as an experimenter, you will need to start from the Feele Lab Experimenter Access page. You then bring up the exact same Experimenter Login screen by clicking on the Login button [Experimenter Login].) If you have logged in successfully, you will see a screen entitled, 'abc1 - View Experiments', where 'abc1' is your username.

To create a new experiment, click on the Add Experiment button. Set the Experiment Type to 'Diamond Dybvig' using the drop-down list and enter 'banking' as the Access Suffix. (The Access Suffix is a code word of your own choosing that your students will need to know to be able to log in to your experiment.)

To add a default session to the new experiment, starting from the View Experiments screen, click on View Sessions to bring up a screen entitled 'Experiment abc1banking (Diamond Dybvig) - View Sessions’. Then click on Add Session to create session \#1.

To change the default configuration values, starting from the View Sessions screen, click on Configure to bring up a screen entitled 'Experiment abc1-banking (Diamond Dybvig) - Configure Session \#1'. There is a Confirm button at the end of the dialog, for saving your changes. There are several configuration values that you may wish to change:

\footnotetext{
${ }^{4}$ http://www.projects.exeter.ac.uk/feele/

${ }^{5} \mathrm{http}: / /$ www.projects.exeter.ac.uk/feele/feele_experiments/subject_access.php?quick=diamond

${ }^{6}$ http://www.projects.exeter.ac.uk/feele/feele_experiments/experimenter_access.php
} 
- Number of Subjects: the number of 'subjects', i.e. student computers; it must be a multiple of the Number of Investors (Group Size) (see below) and defaults to 10. The value you choose for the number of subjects will depend on the size of your class and on the number of computers you have. ${ }^{7}$

- Proceed At Own Pace: we recommend changing this to 'Yes, allow groups to proceed at own pace.', which will allow faster progress. The default option, 'No, wait for all subjects to complete each round.', is slower because individual groups cannot proceed to the next round until all subjects (in all groups) have made a decision in the current round. ${ }^{8}$

- Number of Treatments: if you wish to configure more than one treatment (see example treatments below), you should select 'Two treatments' or 'Three treatments' and click Confirm; additional configuration values for the second and third treatments then appear, which you can change before clicking Confirm for a second time to save your changes.

- Number of Investors (Group Size): the group size, i.e. the total number of investors, both impatient and patient, for each game; it defaults to 10 . The Number of Subjects (see above) must be a multiple of this number. If you change the group size, you must adjust the bank's reserves, i.e. the Bank's Initial Cash On Hand ( $£$ ) and Bank's Initial Investment in Illiquid Asset ( $£$ ); you will almost certainly also wish to adjust the Number of Impatient (Type A) Investors.

- Number of Impatient (Type A) Investors: the number of impatient investors in each group. The default is to have 5 impatient investors in a group of size 10, which implies that there are also 5 patient investors. ${ }^{9}$

- Option \#1: Suspend Payments Until Tomorrow: the maximum number of investors to be paid today, before the bank suspends payments until tomorrow; or 0 (the default) if the bank is not to suspend payments. You can use this option to reduce the likelihood of a bank run by preventing the bank from running out of money. Assuming the default group size of 10 with 5 impatient investors, the bank will not run out of money if it suspends payments after 5 investors have been paid today. ${ }^{10}$

- Option \#2: Deposit Insurance: the percentage of any bad debt from the bank that will be paid by the government; or 0 (the default) if there is no such deposit insurance. You can use this option to reduce the likelihood of a bank run by

\footnotetext{
${ }^{7}$ For example, with a large class of size $50+$ but only 20 computers, you might set the number of subjects to 20, leave the group size set to 10, and ask the students to pair up in twos and three to share a computer. The 20 computers will be divided anonymously into two independent groups, who will each play a 10-investor version of the game.

${ }^{8}$ If you select the 'own pace' option, as recommended, the groups stay the same in all 3 treatments, whereas with the default 'wait for all' option, the subjects are randomly re-grouped between treatments.

${ }^{9}$ If you change the group size, e.g. to 14 instead of the default of 10, you may also wish to adjust the number of impatient investors, in this case to 7 instead of the default of 5, so that you preserve an equal number of impatient and patient investors.

${ }^{10}$ If 6 or more investors decide to withdraw today, the bank selects 5 of them at random to be paid today and defers payment for the remainder until tomorrow, when they are paid alongside those who had originally decided to wait until tomorrow.
} 
guaranteeing that investors will by paid a percentage of whatever the bank owes them, if it runs out of money. ${ }^{11}$

- Payoff Tomorrow to Impatient (Type A) Investor from $£ 1$ Investment (£): the impatient investor's utility from waiting until tomorrow to withdraw $£ R$, where $R$ is the return on the bank's long term investment. ${ }^{12}$ It is always worth less than $£ 1$ to the impatient investor to withdraw $£ R$ tomorrow; default value $£ 0.50$.

- Payoff Tomorrow to Patient (Type B) Investor from $£ 1$ Investment (£): the patient investor's utility from waiting until tomorrow to withdraw $£$ R. It is usually worth $£ R$ (and always worth more than $£ 1$ ) to the patient investor to withdraw $£ R$ tomorrow; default value $£ 2.00$.

- Payoff Today to Bank from 11 Investment in Illiquid Asset (£): (default value E0.50): the return $(<1)$ on the illiquid asset for withdrawals made today; $L$ in the model.

- Payoff Tomorrow to Bank from $£ 1$ Investment in Illiquid Asset (£): (default value E2.00): the return $(>1)$ on the illiquid asset for withdrawals made tomorrow; $\mathrm{R}$ in the model.

- Bank's Initial Cash On Hand (£): the bank usually starts with $£ 1$ per impatient investor held as cash on hand; default value £5.00.

- Bank's Initial Investment in Illiquid Asset (£): the bank usually starts with $£ 1$ per patient investor invested in the illiquid asset; default value $£ 5.00$.

- Number of Paying Rounds: you should configure a minimum of about 5 rounds (default is 1 round), to allow time for the results to converge to one or other equilibrium.

- Grouping Type: we recommend changing to 'Fixed' groupings (default is 'Random'), so that your students remain matched in the same groups of (nominally) 10 subjects during a treatment.

Click on Confirm to save your changes.

To start the session running, starting from the View Sessions screen, click on Start Run; the Status of the session changes from Ready (navy blue) to Running (green). This step is important: your students won't be able to log in if you forget to start the session running! To monitor you students as they log in, you should now click on Monitor Log-Ins to bring up the log-in monitoring screen; this screen has a 10 second auto-refresh by default but you can click on Disable Refresh if it becomes annoying.

To log your students in to the running session, tell them to locate the Feele Lab homepage, as you did, by doing a Google search for the word 'feele' and clicking on the first link, FEELE Laboratory. They should then click on the large-font link Students: Log In here; ${ }^{13}$ the browser opens a new tab showing the Feele Lab Participant Access page and they then click on the Login button [Participant Login]

\footnotetext{
${ }^{11}$ The bank pays whatever it can and then the government pays a percentage of any debt the bank is unable to honour.

${ }^{12}$ Remembering that the bank does not make a profit.

${ }^{13}$ http://www.projects.exeter.ac.uk/feele/feele_experiments/subject_access.php
} 
to bring up the Participant Login screen. In order to log in to your experiment, they need to enter an Access Code, which is 'abc1-banking', where 'abc1' is your username and 'banking' is the Access Suffix that you entered when you created the experiment (see above). Note: if your students are using Internet Explorer, it is also possible to run the Feele website in kiosk mode ${ }^{14}$, as described on the Lecturers: Run Teaching Experiments page.

You should keep an eye on the Monitor Log-Ins screen whilst your students are logging in. If more (or less) students turn up than you had expected, you can use the Change button to adjust the number of subjects upwards (or downwards), but only by a multiple of the group size (default value 10). If a student logs in twice or you have an odd number, you can use the Disconnect button to remove any that are surplus to requirements.

Once everyone has logged in successfully, you must check the box and press the Start Experiment button, to allow your students to start the experiment itself. This step is important: your students are held at a wait screen and won't be able to start reading the instructions or making decisions if you forget to start the experiment! You can now press View Results to see the results monitoring screen, where you can watch your students make their decisions.

\footnotetext{
${ }^{14}$ http://projects.exeter.ac.uk/feele/LecturerStart.shtml\#kiosk
} 


\section{Sample Configuration}

Here is a sample three-treatment configuration for use with groups of 18 students. ${ }^{15}$ Each investor makes a $£ 1$ deposit. Treatment 1 is generated using $\mathrm{R}=2.0$ and $\mathrm{L}=0.5$, whereas treatments 2 and 3 are generated using $R=1.1$ and $L=1 / B$, where $B$ is the number of patient investors; in this case, $\mathrm{B}=9$. Where there is a change to a default configuration value, e.g. for the Number of Impatient (Type A) Investors, this is shown as $\underline{* \boldsymbol{9}}$, where $\underset{*}{*}$ indicates a non-default value.

\begin{tabular}{|c|c|c|c|}
\hline & \multicolumn{3}{|c|}{ Common Configuration Values } \\
\hline Number of Subjects & \multicolumn{3}{|c|}{$* 18$ (or any multiple of 18 ) } \\
\hline Proceed At Own Pace & \multicolumn{3}{|c|}{ *Yes, allow groups to proceed at own pace. } \\
\hline Number of Treatments & \multicolumn{3}{|c|}{ *Three treatments. } \\
\hline & $\begin{array}{l}\text { Treatment } \\
1\end{array}$ & $\begin{array}{l}\text { Treatment } \\
2\end{array}$ & $\begin{array}{c}\text { Treatment } \\
3\end{array}$ \\
\hline $\begin{array}{r}\text { Number of Investors } \\
\text { (Group Size) }\end{array}$ & $* 18$ & $* 18$ & $* 18$ \\
\hline $\begin{array}{r}\text { Number of Impatient (Type } \\
\text { A) Investors }\end{array}$ & $* 9$ & $* 9$ & $* 9$ \\
\hline $\begin{array}{r}\text { Option \#1: } \\
\text { Suspend Payments Until } \\
\text { Tomorrow }\end{array}$ & 0 & 0 & $* 9$ \\
\hline $\begin{array}{r}\text { Option \#2: } \\
\text { Deposit Insurance }\end{array}$ & 0 & 0 & 0 \\
\hline $\begin{array}{r}\text { Payoff Tomorrow to } \\
\text { Impatient (Type A) } \\
\text { Investor from } £ 1 \\
\text { Investment }(£)\end{array}$ & 0.50 & 0.50 & 0.50 \\
\hline $\begin{array}{r}\text { Payoff Tomorrow to } \\
\text { Patient (Type B) Investor } \\
\text { from } £ 1 \text { Investment }(£) \\
\end{array}$ & 2.00 & $* 1.10$ & $* 1.10$ \\
\hline $\begin{array}{r}\text { Payoff Today to Bank from } \\
£ 1 \text { Investment in Illiquid } \\
\text { Asset }(£)\end{array}$ & 0.50 & $* 0.11$ & $* 0.11$ \\
\hline $\begin{array}{r}\text { Payoff Tomorrow to Bank } \\
\text { from } £ 1 \text { Investment in } \\
\text { Illiquid Asset }(£)\end{array}$ & 2.00 & $* 1.10$ & $* 1.10$ \\
\hline $\begin{array}{r}\text { Bank's Initial Cash On } \\
\text { Hand }(£)\end{array}$ & $* 9.00$ & $* 9.00$ & $* 9.00$ \\
\hline $\begin{array}{r}\text { Bank's Initial Investment } \\
\text { in Illiquid Asset (£) }\end{array}$ & $* 9.00$ & $* 9.00$ & $* 9.00$ \\
\hline Number of Paying Rounds & $* 8$ & $* 10$ & $* 5$ \\
\hline Grouping Type & *Fixed & *Fixed & *Fixed \\
\hline
\end{tabular}

The following table is in a similar format to the non-computerized experiment and shows, for the above configuration, the expected payment received by a patient

\footnotetext{
${ }^{15}$ An identical configuration was used to generate the computerized results detailed below.
} 
investor, related to how many other patient investors wait until tomorrow to withdraw. ${ }^{16}$

\begin{tabular}{|c|c|c|c|c|c|c|c|c|c|}
\hline $\begin{array}{r}\text { Of the } 8 \text { other patient } \\
\text { investors, the } \\
\text { number who } \\
\text { withdraw tomorrow }\end{array}$ & 0 & 1 & 2 & 3 & 4 & 5 & 6 & 7 & 8 \\
\hline $\begin{array}{r}\text { Expected payment to } \\
\text { patient investor } \\
\text { withdrawing } \\
\text { tomorrow in } \\
\text { treatment } 1 \\
\end{array}$ & $\begin{array}{c}£ 0.0 \\
0\end{array}$ & $\begin{array}{c}£ 0.0 \\
0\end{array}$ & $\begin{array}{c}£ 0.0 \\
0\end{array}$ & $\begin{array}{c}£ 0.0 \\
0\end{array}$ & $\begin{array}{c}£ 0.4 \\
0\end{array}$ & $\begin{array}{c}£ 1.0 \\
0\end{array}$ & $\begin{array}{c}£ 1.4 \\
3\end{array}$ & $\begin{array}{c}£ 1.7 \\
5\end{array}$ & $\begin{array}{c}£ 2.0 \\
0\end{array}$ \\
\hline $\begin{array}{r}\text { Expected payment to } \\
\text { patient investor } \\
\text { withdrawing today in } \\
\text { treatment } 1\end{array}$ & $\begin{array}{c}£ 0.7 \\
5\end{array}$ & $\begin{array}{c}£ 0.7 \\
9\end{array}$ & $\begin{array}{c}£ 0.8 \\
4\end{array}$ & $\begin{array}{c}£ 0.9 \\
0\end{array}$ & $\begin{array}{c}£ 0.9 \\
6\end{array}$ & $\begin{array}{c}£ 1.0 \\
0\end{array}$ & $\begin{array}{c}£ 1.0 \\
0\end{array}$ & $\begin{array}{c}£ 1.0 \\
0\end{array}$ & $\begin{array}{c}£ 1.0 \\
0\end{array}$ \\
\hline $\begin{array}{r}\text { Expected payment to } \\
\text { patient investor } \\
\text { withdrawing } \\
\text { tomorrow in } \\
\text { treatment } 2 \\
\end{array}$ & $\begin{array}{c}£ 0.0 \\
0\end{array}$ & $\begin{array}{c}£ 0.0 \\
0\end{array}$ & $\begin{array}{c}£ 0.0 \\
0\end{array}$ & $\begin{array}{c}£ 0.0 \\
0\end{array}$ & $\begin{array}{c}£ 0.0 \\
0\end{array}$ & $\begin{array}{c}£ 0.0 \\
0\end{array}$ & $\begin{array}{c}£ 0.0 \\
0\end{array}$ & $\begin{array}{c}£ 0.0 \\
0\end{array}$ & $\begin{array}{c}£ 1.1 \\
0\end{array}$ \\
\hline $\begin{array}{r}\text { Expected payment to } \\
\text { patient investor } \\
\text { withdrawing today in } \\
\text { treatment } 2 \\
\end{array}$ & $\begin{array}{c}£ 0.5 \\
6\end{array}$ & $\begin{array}{c}£ 0.5 \\
9\end{array}$ & $\begin{array}{c}£ 0.6 \\
3\end{array}$ & $\begin{array}{c}£ 0.6 \\
7\end{array}$ & $\begin{array}{c}£ 0.7 \\
1\end{array}$ & $\begin{array}{c}£ 0.7 \\
7\end{array}$ & $\begin{array}{c}£ 0.8 \\
3\end{array}$ & $\begin{array}{c}£ 0.9 \\
1\end{array}$ & $\begin{array}{c}£ 1.0 \\
0\end{array}$ \\
\hline $\begin{array}{r}\text { Expected payment to } \\
\text { patient investor } \\
\text { withdrawing } \\
\text { tomorrow in } \\
\text { treatment } 3 \\
\end{array}$ & $\begin{array}{c}£ 1.1 \\
0\end{array}$ & $\begin{array}{c}£ 1.1 \\
0\end{array}$ & $\begin{array}{c}£ 1.1 \\
0\end{array}$ & $\begin{array}{c}£ 1.1 \\
0\end{array}$ & $\begin{array}{c}£ 1.1 \\
0\end{array}$ & $\begin{array}{c}£ 1.1 \\
0\end{array}$ & $\begin{array}{c}£ 1.1 \\
0\end{array}$ & $\begin{array}{c}£ 1.1 \\
0\end{array}$ & $\begin{array}{c}£ 1.1 \\
0\end{array}$ \\
\hline $\begin{array}{r}\text { Expected payment to } \\
\text { patient investor } \\
\text { withdrawing today in } \\
\text { treatment } 3\end{array}$ & $\begin{array}{c}£ 1.0 \\
5\end{array}$ & $\begin{array}{c}£ 1.0 \\
5\end{array}$ & $\begin{array}{c}£ 1.0 \\
4\end{array}$ & $\begin{array}{c}£ 1.0 \\
4\end{array}$ & $\begin{array}{c}£ 1.0 \\
4\end{array}$ & $\begin{array}{c}£ 1.0 \\
3\end{array}$ & $\begin{array}{c}£ 1.0 \\
3\end{array}$ & $\begin{array}{c}£ 1.0 \\
2\end{array}$ & $\begin{array}{c}£ 1.0 \\
1\end{array}$ \\
\hline
\end{tabular}

Treatments 1 and 2 have two pure-strategy equilibria, whereas treatment 3 has a single equilibrium. (Note that the expected payment to a patient investor withdrawing today in treatment 3 is higher than $£ 1$ since there is a chance that he will not receive the $£ 1$ today. If there is already a suspension of payments, the investor may be forced to withdraw tomorrow.)

In treatment 1 , one is better off withdrawing tomorrow so long as one believes that at least 6 others will do so, otherwise it makes sense to withdraw today. ${ }^{17}$ This treatment can converge either to the normal equilibrium (all withdraw tomorrow) or to the bank run equilibrium (all withdraw today).

In treatment 2, one is better off withdrawing tomorrow if one believes that all 8 others will do so, otherwise it makes sense to withdraw today. This treatment rapidly converges to the bank run equilibrium because it only requires one investor to panic and withdraw early for the bank to run out of money.

\footnotetext{
${ }^{16}$ It is reasonable to assume that the 9 impatient investors are rational and therefore all withdraw today.

${ }^{17}$ Indifferent between today and tomorrow if 5 others withdraw tomorrow.
} 
In treatment 3, it always makes sense to withdraw tomorrow, regardless of how many others do so.

\section{Hints and Tips}

Before running this experiment for the first time with real students, it is a good idea to set aside a few minutes to configure and run a short test session where you log in dummy subjects using multiple browser tabs and play, say, 1 round of each treatment, just to gain familiarity with the computer interface.

Just as with the non-computerized version of this experiment, if you have a high percentage of students for whom English is not a first language, it will speed up the class if you email or circulate the Part 1 instructions to the students in advance.

It will speed up the logging in process if you circulate hand-outs to the students explaining what to do; if you number the hand-outs beforehand, it will make it easier to count up how many students there are when configuring the software. 


\section{Some results and suggestions for classroom discussion}

\section{Results from a computerized session}

The following figure shows the results of a classroom experiment run in Exeter on a single group of 18 students. ${ }^{18}$ Investor types (roles) were randomly re-allocated at the start of every round, with 9 students being type A (impatient) investors and 9 students type B (patient) investors. The experiment lasted 23 rounds and there were 3 treatments. In the first treatment, lasting 8 rounds, conditions were set for $\mathrm{R}=2$ and $\mathrm{L}=.5$ (we call this 'normal conditions'). Toward the last few rounds of this treatment, the students settled into the normal equilibrium. Type A's withdrew today and type B's withdrew tomorrow. In the second treatment, lasting 10 rounds, we had $\mathrm{R}=1.1$ and $\mathrm{L}=.11$. We might refer to this as a 'credit crunch'. Tight conditions for the bank: not much leeway if depositors try to withdraw early. In this treatment, there was a run on the bank. In the third treatment, lasting 5 rounds, we also had $\mathrm{R}=1.1$ and $\mathrm{L}=.11$, but payments were halted after 9 depositors withdrew from the bank early. This suspension stopped the run on the bank. There was an instant effect that steadily improved.

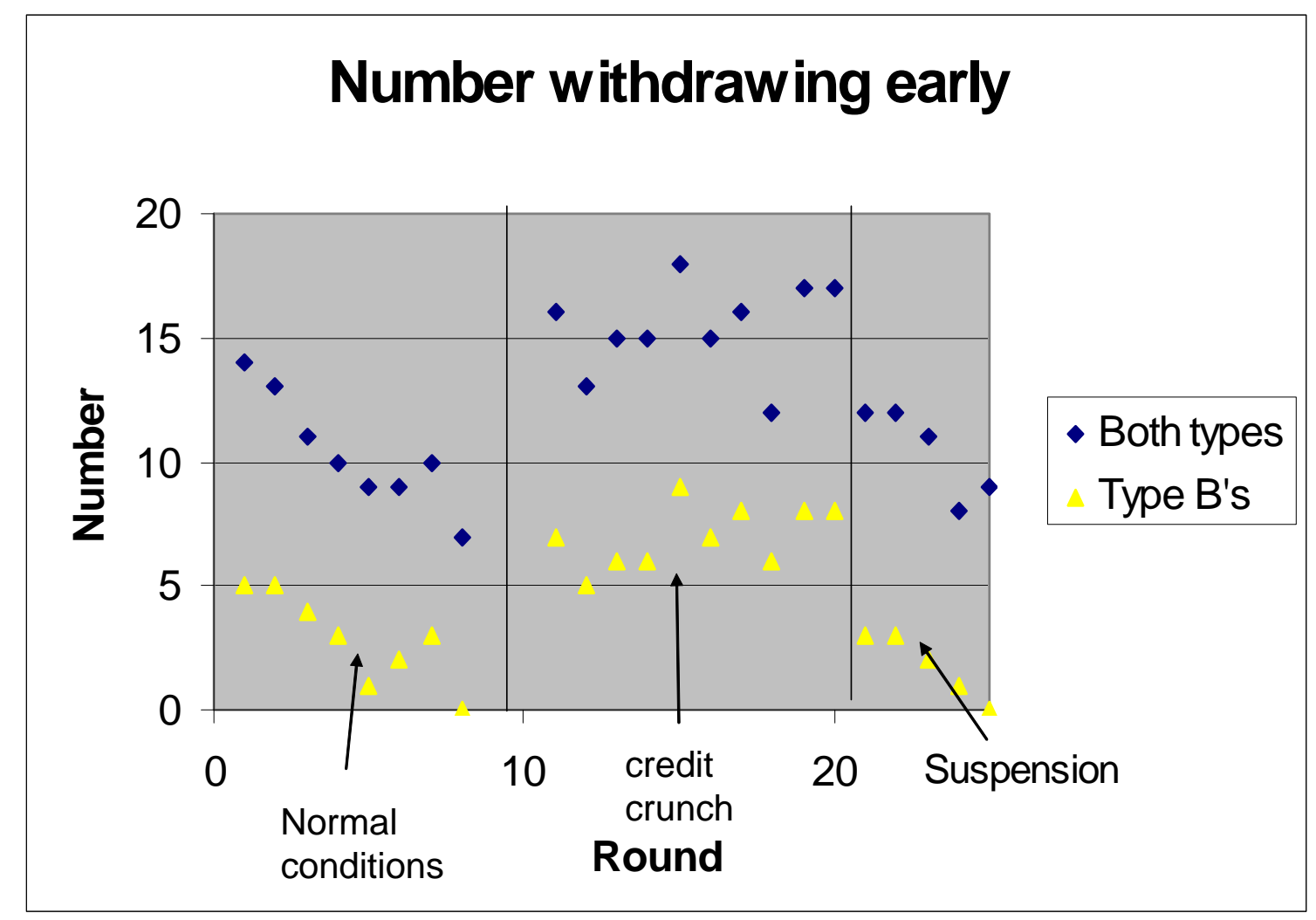

\section{Suggestions for classroom lectures and discussion}

\footnotetext{
${ }^{18}$ There were 18 computer terminals and the students were paired up with an average of two to a computer.
} 
As mentioned before, it is desirable to run the experiment before the lecture. I then like to show video clips from two Hollywood movies: Mary Poppins and It's A Wonderful Life. These can really liven up a lecture. Mary Poppins is able to show how runs can start from rumours and how banks close their doors to stop further withdrawals. It's A Wonderful Life shows how a systemic risk can cause a run. Jimmy Stewart also explains how a bank works by borrowing short and lending long. The movie also explains why a suspension can cause significant damage to depositors (some need money to live).

After this, one can start explaining the Diamond-Dybvig model as described above. If the students have studied normal form games, the reduced version of the game between two patient depositors captures the intuition of how there are two (purestrategy) equilibria.

After explaining the model, one can bring up some of the many examples of modern bank runs. After this, one can explain possible policies that could help prevent bank runs in the future and what is missing from the model.

\section{Modern Bank Runs.}

We first started developing this classroom experiment before the Northern Rock bank run, so it is surprising in some sense to see many examples of modern bank runs. Here is a selection of some of the major ones.

\section{Northern Rock}

The most visible bank run in the UK was the 2007 run on Northern Rock. There were long queues of depositors outside the bank. As we learned, it was perfectly rational for depositors to want to withdraw their money early. Northern Rock did not follow the Diamond-Dybvig model precisely by taking money from depositors and investing part of it in the long-term investment. Instead, they invested amounts far beyond their levels of deposits. Naturally, this money had to come from somewhere and Northern Rock met this shortfall by borrowing from other banks. In essence, other banks became the depositors. When the subprime crisis hit, the mortgages that Northern Rock made were still performing, the problem was that these other banks acting as depositors became impatient and "withdrew" their money.

\section{Etrade}

In the era of Internet banking, a bank run takes a whole new form. While Etrade may have had sufficient insurance to cover almost all of its deposits, there was a run on the bank (participated in by one of the authors) since it was easier to transfer money out than to read in detail the deposit insurance description. Etrade survived (so far), but suffered significant damage in both reputation and by the necessity of having to liquidate billions in assets. Now Etrade makes sure their deposit insurance is well known.

\section{Bear Stearns}

Bear Stearns was an investment bank founded in 1923 and in 2007 had 14,000 employees. It focused on stock investments, hedge funds and brokerage (based upon the historical division of banks). Customers were firms and professionals. The market cap was at \$20 billion in 2007 (\$170 per share). Two hedge funds lost 
billions in 2007. On March 11, 2008, there was a "bank run”. Money was withdrawn from accounts, within two days capital balance went from \$17 billion to \$2 billion. They couldn't sell assets instantly to cover demand and needed to borrow \$30 billion. On Friday, March $14^{\text {th }}$, 2008, the Fed guaranteed a loan of $\$ 30$ billion from JP Morgan to Bear Sterns. On Sunday, March 16th, 2008 it was announced that JP Morgan would buy the company for $\$ 2$ a share (200 million total) later raised to $\$ 10 /$ share. This is about the value of their building on Wall Street (worth more than 1 billion dollars).

As Krugman (2007) points out, in today's financial world, a modern bank run does not have to be standing in a queue nor even have to happen at a bank. It can happen at hedge funds and many other financial institutions that borrow short-term and lend long-term.

\section{Iceland}

At the beginning of 2008, Iceland had a GDP of about 20 billion pounds (population of 300,000). Icelandic banks had deposits of 120 billion pounds (in foreign currencies). They lent the money to groups that bought assets. There was a run on Iceland and the country had to nationalize the three main banks. They suspended payments to a half million depositors: including many UK city councils (almost 1 billion pounds worth) and universities. The Icelandic government was only responsible for the first 15,000 pounds, but still is struggling to pay this amount.

\section{Lehman Brothers}

On September 15, 2008, Lehman Brothers with over 600 billion in assets filed for bankruptcy. The US government decided to let it fall. It isn't clear whether there was a solvency or a liquidity problem. Still, this decision was controversial and may be considered a mistake of the magnitude of when the Fed allowed the Bank of the United States to fail in 1930 with 400,000 depositors, of which Friedman and Schwarz (1963) say helped steer the US into the great depression. History will help tell us how large the contagion effect was from the collapse of Lehman and whether avoiding this would have been worth a bailout. As for the Bank of the United States, it eventually paid 80 cents on the dollar and that was in the Great Depression.

\section{Washington Mutual}

On September 25, 2008, Washington Mutual went bankrupt after a 10-day bank run with withdrawals of $\$ 17$ billion. This was the largest US banking failure to date. Washington Mutual had assets of \$330 billion and 50,000 employees.

\section{Prevention:}

Now one can explain possible ways to help avoid a bank run or lower the effect.

Signalling. One of the older techniques was to put money in the windows of the bank. This is sending a signal that the bank has enough money so there is no need to panic. There are modern day equivalent of signals such as getting a large investment from Warren Buffett (as Goldman Sachs did). 
Suspension of payments. What was done in the past was to suspend payments. This is closing the doors and preventing further withdrawals. We saw this was effective in the experiment, but there is a problem when the number needing money today is uncertain. One may also want to discuss when a partial suspension may help (lowering payments the larger the number that try to withdraw). Also, instead of a suspension, a bank may try to slow down payments.

Coordination. Another way to avoid a bank run is when there are a limited number of depositors. We can have what is called creditor coordination. We saw this with Long Term Capital Management, a large hedge fund that ran into trouble in 1998. Their problems were similar to a bank run, in that all the creditors demanded their money, which suppressed the value of LTCM's assets. This run was stopped by a legendary meeting organized by the NY FED with the creditors. Another famous creditor coordination meeting was held by JP Morgan (himself) in the 1907 banking panic.

Lender of Last Resorts. Another solution is using the lender of last resort. Central bank steps in and loans the bank money to replace deposits. This should work with depositors in the case of a problem with simple liquidity. The danger is that it creates a moral hazard problem (see below). For instance, in 2007 both Northern Rock and Countrywide ran into problems. Countrywide had bothered to secure lines of credit ahead of time (at an expense) if it ran into trouble. Myopic Northern Rock did not. If the Bank of England simply lent Northern Rock money, it might encourage other banks not to bother obtaining lines of credit in the future.

One needs to be careful about using this facility. In 1975, April 14th, Credit Suisse announced that it had lost some money in one of its branches. It didn't mention details. April 25th, The Swiss Central Bank announced it was willing to lend money. This had the opposite result causing share price to tumble $20 \%$.

Narrow banking.

We said that bank runs are inherent if the bank serves to convert short term demands into long term investments. Another idea which dates back to Milton Friedman (1948) (also see Shy and Stenbacka, 2008) is for narrow banking, that is where each bank keeps $100 \%$ of its deposits as reserves. This has the advantage of preventing bank runs, but then consumers would have to pay more for banking services.

\section{Deposit Insurance.}

The final tool that is useful to prevent bank runs is Deposit Insurance. If the amount you have in the bank is fully insured, you have no incentive to try to withdraw early. However there may be a delay before one gets payment. Also, the deposit insurance scheme may not be foolproof. As with Iceland, even if a government backs the scheme, there is still the possibility of sovereign debt default. Also, usually, deposit insurance is not $100 \%$ of all deposits. It can be capped and as we saw in the UK it was only partially covered until the cap. This still left open the possibility of a rational bank run.

\section{Missing from the model.}


The Diamond-Dybvig model is beautiful in its simplicity, but this simplicity comes at a cost. It is also worthwhile to discuss what is not captured in the model. Two important elements missing from the model are uncertainty and moral hazard.

Uncertainty. There may be uncertainty in depositors' preferences. So far we assumed there was no aggregate uncertainty, that is, there is exactly one impatient depositor for every patient depositor. In reality, there may be changing macroeconomic conditions that cause more than the usual number of depositors actually to need the money today. This makes a suspension less desirable as a mechanism to stop bank runs since the bank would also be preventing those that actually need the money from withdrawing.

Another thing lacking from the basic model is the riskiness in the long-term investment. There can be riskiness in R. Perhaps sometimes there really isn't enough money to meet demand tomorrow. In such cases, it will be worthwhile to withdraw money independent of what others do. Thus, sometimes a bank run will be unique. This also brings us the issue of opacity of the investment and how much of the true return is known to depositors (see Kaplan 2006). With the sub-prime crisis we saw that the return from mortgage based derivatives was indeed risky and at least for a while the status of the investments was unknown to the depositors.

There can also be riskiness in L. Perhaps, at times of a systemic problem, the liquidation value is lower. At Long Term Capital Management, the mere fact that LTCM owned an asset lowered that asset's value (see Lowenstein 2000).

Moral hazard. Probably the most important element missing from the model is moral hazard. The basic idea comes from insurance. Say you buy theft insurance for a laptop. Because you buy the insurance, you may be more likely to leave the laptop in your car when you pick up the milk on the way back from work. Ideally, you would like to commit to not leaving the computer in your car (computer thieves love to hang around convenience stores waiting for prey). Sometimes, we can contract on it (most current theft insurance for laptops do not cover theft if it is left in a car). Other times, we can't.

It is thought that a moral hazard problem is created when there is deposit insurance (see Kane, 1989). In the 1980s over a thousand Savings and Loan banks in the US went bankrupt. They originally lent money out at fixed rates of $6 \%$ and paid deposits $3 \%$. However, starting in the mid 1970's high inflation rates forced the banks to pay interest rates upwards of $10 \%$ (higher than 6\%). Since their balance sheets were in trouble, they decided to take higher risk in an attempt to overcome their deficits. They lent money to riskier clients such as Latin American countries. Ultimately, the Savings and Loans crisis cost US taxpayers \$120 billion.

The banks were able to take high risk due to the deposit insurance. In most cases, depositors did not care whether or not their bank took risks since they knew their deposits were insured. This in essence has the insurance corporation subsidize the risky behaviour. It is possible that for this reason, deposits in the UK were not fully 
insured and why in many cases the insured amount is capped. ${ }^{19}$ Bearing some risk would give the depositors incentive to be wary of banks taking on excess risk. (One may ask whether depositors are able to check the riskiness of a bank's portfolio and whether this should be their job.) Unfortunately, while a co-pay insurance may reduce the moral hazard problems, it keeps the multiple equilibrium problem, as the UK discovered. At least one way to ameliorate the problem is to base deposit insurance premiums upon risk. The US did just that with Federal Deposit Insurance Reform Act of 2005, allowing the FDIC to charge premiums based upon risk.

\section{Conclusion}

In this paper, we demonstrated how bank runs can occur in a simple classroom experiment and that they are inherent in any institution which borrows short term and lends long term. We end the paper how we would end a lecture. In the episode "The PTA Disbands” of The Simpsons, the bank run of It's A Wonderful Life is parodied. Bart Simpson starts a bank run and the Jimmy-Stewart-like bank manager explains how he doesn't have the money: "It's at Bill's house and Fred's house!" Moe sees Fred and says, "What the heck are you doing with my money in your house?", and punches him. Hopefully, after this lecture the nature of banking and bank runs will not be so confusing to your students.

\footnotetext{
${ }^{19}$ Before the subprime crisis, the UK had $100 \%$ of deposits covered up to $£ 2000$ and $90 \%$ of those between $£ 2000$ and $£ 33000$. At that time, the US had FDIC insurance of $\$ 100,000$. Since then the UK has increased the insurance to $100 \%$ of the first $£ 50,000$ and the US increased the insurance to $\$ 250,000$.
} 


\section{References}

Diamond, D. W., and P. H. Dybvig 1983. Bank Runs, Deposit Insurance, and Liquidity. Journal of Political Economy. v91: 401-19.

Friedman, M. 1948. A monetary and fiscal framework for economic stability. American Economic Review, 38 (3), 245-264.

Friedman, M. and A.J. Schwartz 1963. Monetary History of the United States, 18671960. Princeton University Press.

Kane, Edward J. 1989. The S\&L Insurance Mess: How Did It Happen? Washington, DC: The Urban Institute.

Kaplan, Todd. 2006. Why Banks Should Keep Secrets, Economic Theory, 27, 341357.

Krugman, Paul. 2007. It’s a Miserable Life, New York Times. August 20, 2007.

Lowenstein, R. 2000. When genius failed: the rise and fall of Long-Term Capital Management. New York: Random House.

Shy, O., and R. Stenbacka 2008. Rethinking the Roles of Banks: A Call for Narrow Banking. The Economists' Voice, 5(2), Article 6.

Vriend, N.J. 2000. Demonstrating the Possibility of Pareto Inferior Nash Equilibria. Journal of Economic Education, v31 (4): 358-362 


\section{Instructions for Banking Experiment.}

1. You are a depositor and have your money in a bank. You have to decide whether to withdraw today at time 1 or tomorrow at time 2. There are 6 other depositors that have to make the same decision. The bank only has a limited number of reserves and if too many try to withdraw today, it will have to sell an illiquid asset and be unable pay the full amount promised tomorrow.

2. At the beginning of the lecture, you will receive 5 strips of paper - one for each of five rounds of the experiment. About half of you will receive white coloured strips of paper and the other half green strips of paper.

3. At the beginning of each round, on the strip of paper you will have to write (a) the round, (b) your name, and (c) circle your decision: either "1" (withdraw today ) or " 2 " (withdraw tomorrow). The instructor will then collect the strips from everyone.

4. The instructor will select 6 white AND 6 green strips for that round. The instructor will then write the 6 decisions for each colour on the board. These decisions will represent the decisions of the other 6 depositors in your group. Your profits for that round will be determined according to the following table.

\begin{tabular}{|l|l|l|l|l|l|l|l|}
\hline $\begin{array}{l}\text { Of the 6 others in } \\
\text { your group, the } \\
\text { number that choose 2 }\end{array}$ & 0 & 1 & 2 & 3 & 4 & 5 & 6 \\
\hline $\begin{array}{l}\text { Your amount if you } \\
\text { choose 2 and are in a } \\
\text { white group. }\end{array}$ & $£ 0$ & $£ 0$ & $£ 0$ & $£ 0$ & $£ 0$ & $£ 4$ & $£ 12$ \\
\hline $\begin{array}{l}\text { Your amount if you } \\
\text { choose } 1 \text { and are in a } \\
\text { white group }\end{array}$ & $£ 6$ & $£ 6$ & $£ 7$ & $£ 8$ & $£ 8$ & $£ 9$ & $£ 10$ \\
\hline $\begin{array}{l}\text { Your amount if you } \\
\text { choose 2 and are in a } \\
\text { green group. }\end{array}$ & $£ 0$ & $£ 8$ & $£ 13$ & $£ 16$ & $£ 18$ & $£ 19$ & $£ 20$ \\
\hline $\begin{array}{l}\text { Your amount if you } \\
\text { choose } 1 \text { and are in a } \\
\text { green group. }\end{array}$ & $£ 9$ & $£ 10$ & $£ 10$ & $£ 10$ & $£ 10$ & $£ 10$ & $£ 10$ \\
\hline
\end{tabular}

5. The instructor will then select one more white strip and one more green strip. The instructor will demonstrate the calculation of the amount for that $7^{\text {th }}$ depositor.

6. The experiment will repeat for 5 rounds from step 3.

Please make sure you understand the instructions before class but please do not discuss this before class.

Good luck. 